\title{
HANDHELD FINGER TECHNIQUE RELAXATION AND MUSIC THERAPY TO DECREASE ANXIETY IN PRE SECTIO CAESAREA PATIENTS
}

\author{
Arina Ma'rufa', Kurniati Puji Letari ${ }^{2}$, Elisa $^{2}$ \\ ${ }^{1}$ Student of Applied Undergraduate Nursing Study Program at the Health Polytechinc of \\ Semarang \\ ${ }^{2}$ Lecturer in Nursing Department of Health Polytechnic of Semarang \\ Corresponding author: arinamarufa@gmail.com
}

\begin{abstract}
Background: There are still many pre-sectional caesarean patients who are increasing the number of surgical stressors that cause fear because they cause surgical action. In addition, patients must undergo psychological surgery during this operation are ignored and do not need to be treated because of psychological difficulties performed by the patient before surgery.

Purpose: To find out the combination of the effect of handheld finger technique relaxation and music therapy to decrease of anxiety in patients with pre-Sectio Caesarea.

Method: This research used a Pre-Experimental Design with a One-Group pre-post test design. The sampling technique uses accidental sampling. The number of respondents of Sectio Caesarea patients was 33 respondents. The instrument used was the Zung Self Anxiety Rating Scale (ZSARS) questionnaire.

Results: The results of the study showed that the pre-sectional caesarean patients were given an intervention with a mild level of difficulty and after being given an intervention regarding the coverage, they were not worried. The Wilcoxon test results showed a $\mathrm{p}$ value of $0,000(\mathrm{p}<0.05)$.

Conclusion: The combination of handheld finger relaxation techniques and music therapy has an effect to decreasing anxiety in pre-sectional caesarean patients.

Keywords: Handheld Finger Technique Relaxation, Music Therapy, Anxiety, Sectio Caesarea

\section{LATAR BELAKANG}

Persalinan merupakan kejadian fisiologis yang dialami oleh seorang ibu berupa pengeluaran hasil konsepsi yang hidup di dalam uterus melalui vagina ke dunia luar. Terdapat dua cara persalinan yaitu persalinan secara normal dan persalinan dengan operasi sectio caesarea (SC). Sectio caesarea adalah kelahiran janin melalui insisi yang dibuat pada dinding abdomen dan uterus (Reeder, Martin, \& Koniak-Griffin, 2011).
\end{abstract}


Tindakan sectio caesarea merupakan salah satu faktor stressor bagi seorang ibu saat hamil. Seseorang mengalami cemas, gelisah dan takut saat mengahadapi pembedahan atau operasi, karena tindakan operasi akan membangkitkan reaksi stress baik secara psikologis maupun secara fisiologis yang salah satu respon stressnya adalah cemas, dan dalam rentang waktu saat menunggu pelaksanaan operasi akan menyebabkan kecemasan pada pasien (Simbolon \& Hondro, 2015). Salah satu tindakan operasi atau pembedahan yaitu sectio caesarea yang merupakan salah satu bentuk intervensi medis terencana yang biasanya memerlukan waktu cukup lama dan membutuhkan pengendalian pernafasan, sehingga sangat beresiko terhadap keselamatan jiwa seseorang dan dapat menyebabkan pasien mengalami kecemasan (Ghofur, 2009 dalam Pawatte 2013). Berdasarkan penelitian yang dilakukan Yanti, Anggraeni, Sulistianingsih dan Maryanti (2016), didapatkan hasil penelitian sebagian besar responden dari total responden sebanyak 42 responden yang akan menjalani operasi sectio caesarea di ruang kebidanan RS Urip Sumoharjo Bandar Lampung pada tahun 2015 mengalami tingkat kecemasan ringan sebanyak 16 responden $(38,1 \%)$, yang mengalami kecemasan sedang sebanyak 14 responden $(33,3 \%)$ dan sisanya tidak mengalami kecemasan.

Perawatan pre operasi yang efektif untuk mengurangi resiko post operasi, salah satu prioritas tindakan keperawatan pada fase ini adalah mengurangi kecemasan pasien pre operasi (Yanti, dkk. 2016). Bila kecemasan tidak mendapat penanganan yang adekuat, terdapat kemungkinan kecemasan dapat bertambah parah yang akan berdampak pada ketidaksiapan pasien untuk menjalani proses operasi (Simbolon \& Hondro, 2015). Kecemasan pada pasien pre operasi harus diatasi karena akan menimbulkan berbagai resiko diantaranya perubahan fisiologi yang dapat menghambat dilakukannya tindakan operasi karena pada pasien pre operasi yang mengalami kecemasan akan menimbulkan kelaianan seperti peningkatan tekanan darah, sehingga apabila operasi tetap dilakukan akan mengakibatkan penyulit terutama dalam menghentikan perdarahan dan bahkan setelah operasi dilakukan akan mengganggu proses penyembuhan (Breathesy, 2009). Karena hal tersebut peran perawat sangat diperluan untuk melakukan intervensi kepada pasien dari pre sampai post operasi, hal yang dapat dilakukan perawat yaitu melalukan berbagai terapi misalnya terapi meditasi, terapi imajinasi, dan terapi relaksasi (Rokawie, Sulastri, \& Anita, 2017).

Berbagai penelitian untuk mengatasi kecemasan pre operasi telah banyak dilakukan namun belum ada satupun yang direkomendasikan yang efektif untuk mengatasi kecemasan ini. Kecemasan dapat ditangani dengan cara farmakologis dan non farmakologis. Dalam penanganan farmakologis menggunakan obat anti ansietas misalnya benzodiazepine, hanya digunakan untuk jangka pendek karena pengobatannya bersifat ketergantungan. Sedangkan untuk cara non farmakologis dapat ditangani dengan teknik relaksasi, psikoterapi dengan hipnoterapi. Salah satu teknik relaksasi yang dapat digunakan untuk penanganan kecemasan adalah teknik relaksasi genggam jari. Teknik relaksasi genggam jari merupakan teknik yang sederhana dan mudah untuk dilakukan. Selain menggunakan teknik relaksasi 
genggam jari, teknik yang dapat digunakan untuk menangani kecemasan adalah menggunakan teknik terapi musik. Menurt tenaga dokter di Sydney yang beranggapan bahwa music dapat digunakan sebagai pengobatan untuk anti kecemasan terutama pada pasien dengan kondisi kritis. Implementasi dari terapi music dapat mengurangi tingkat kecemasan yang akan berkaitan dengan proses pemulihan yang lebih cepat.

\section{TUJUAN}

Untuk mengetahui pengaruh teknik genggam jari dan terapi musik terhadap penurunan kecemasan pasien pre Sectio Caesarea.

\section{METODE}

Penelitian ini menggunakan desain penelitian pra experimental one group pre-post test design. Penelitian ini dilakukan di RSUD Ungaran pada Mei 2019. Populasi pada penelitian adalah pasien pre sectio caesarea di RSUD Ungaran yang mengalami kecemasan sebanyak 33 orang. Teknik sampling dengan accidental sampling berdasarkan rumus Lameshow didapatkan responden sebanyak 33 orang.

Kriteria inklusi pada penelitian ini adalah pasien pre sectio caesarea yang mengalami kecemasan ringan sampai sedang, tidak memiliki gangguan pendengaran, bersedia menjadi responden, kooperatif. Instrumen pada penelitian ini adalah kuesioner Zung Self-Rating Anxiety Scale (ZS-RAS). Analisa data dengan menggunakan uji Wilcoxon.

\section{HASIL}

\section{Karakteristik Responden}

Tabel 1 Karakteristik Ibu Pre Sectio Caesarea Berdasarkan Usia, Pendidikan dan Riwayat Sectio Caesarea April - Mei 2019 (n=33)

\begin{tabular}{lcc}
\hline Karakteristik & $f$ & $\%$ \\
\hline Usia & & \\
26 tahun & 1 & 3,0 \\
27 tahun & 2 & 6,1 \\
28 tahun & 4 & 12,1 \\
29 tahun & 1 & 3,0 \\
30 tahun & 5 & 15,2 \\
31 tahun & 5 & 15,2 \\
32 tahun & 1 & 3,0 \\
33 tahun & 3 & 9,1 \\
34 tahun & 4 & 12,1 \\
35 tahun & 2 & 6,1 \\
36 tahun & 2 & 6,1 \\
37 tahun & 1 & 3,0 \\
40 tahun & 1 & 3,0
\end{tabular}


Tabel Lanjutan

\begin{tabular}{lll}
\hline Karakteristik & $f$ & $\%$ \\
\hline Pendidikan & & \\
SD & 4 & 12,1 \\
SMP & 7 & 21,2 \\
SMA & 15 & 45,5 \\
PT & 7 & 21,2 \\
Riwayat SC & & \\
Pertama & 25 & 75,8 \\
Kedua & 8 & 24,2 \\
\hline
\end{tabular}

Berdasarkan hasil analisa dari tabel 1 menunjukkan bahwa karakteristik usia responden mayoritas pada usia 30 dan 31 tahun sebanyak masing-masing 5 responden $(15,2 \%)$ dan paling sedikit pada usia 26, 29, 32, 37, 40, dan 41 tahun masing-masing sebanyak 1 responden $(3,0 \%)$.

Karakteristik responden berdasarkan pendidikan ibu pre sectio caesarea yang terbanyak dengan tingkat pendidikan SMA sebanyak 15 responden $(45,4 \%)$ dan yang paling sedikit dengan tingkat pendidikan SD sebanyak 4 responden $(12,1 \%)$. Karakteristik responden berdasarkan riwayat sectio caesarea yang terbanyak dengan riwayat sectio caesarea pertama sebanyak 25 responden $(75,8 \%)$ dan yang paling sedikit dengan riwayat sectio caesarea kedua sebanyak 8 responden $(24,2 \%)$.

Gambaran Tingkat Kecemasan Sebelum dan Sesudah dilakukan Intervensi Kombinasi Teknik Relaksasi Genggam Jari dan Terapi Musik

Tabel 2 Tingkat Kecemasan Responden Sebelum dan Sesudah dilakukan Intervensi Kombinasi Teknik Relaksasi Genggam Jari dan Terapi Musik bulan April - Mei $2019(n=33)$

\begin{tabular}{ccccccc}
\hline & \multicolumn{2}{c}{ Tidak Cemas } & \multicolumn{2}{c}{$\begin{array}{c}\text { Kecemasan } \\
\text { Ringan }\end{array}$} & \multicolumn{2}{c}{ Kecemasan Sedang } \\
\cline { 2 - 7 } & $f$ & $\%$ & $f$ & $\%$ & $f$ & $\%$ \\
\hline Pre test & - & - & 24 & 72,7 & 9 & 27,3 \\
Post test & 21 & 63,6 & 11 & 33,3 & 1 & 3,0 \\
\hline
\end{tabular}

Berdasarkan tabel 2 menunjukkan bahwa gambaran kecemasan pada responden sebelum dilakukan kombinasi teknik relaksasi genggam jari dan terapi musik yaitu responden dengan tingkat kecemasan sedang sebanyak 9 responden $(27,3 \%)$ dan tingkat kecemasan ringan sebanyak 24 responden $(72,7 \%)$. Setelah diberikan 
intervensi kombinasi teknik relaksasi genggam jari dan terapi musik, jumlah responden yang terjadi penurunan kecemasan menjadi tidak cemas sebanyak 21 responden $(63,6 \%)$, yang mengalami penurunan kecemasan menjadi ringan 11 responden $(33,3 \%)$ dan masih terdapat 1 responden $(3,0 \%)$ yang masih mengalami kecemasan sedang.

Perbedaan Tingkat Kecemasan Pre dan Post Test Ibu Pre Sectio Caesarea di RSUD Ungaran

Tabel 3 Hasil Perbedaan Tingkat Kecemasan Pre-Post Test Ibu Pre Sectio Caesarea Ungaran April - Mei 2019 (n=33)

\begin{tabular}{ccccccc}
\hline & $\mathrm{n}$ & Mean & Std. Deviation & Min & Max & Sig. \\
\hline Pre Test & 33 & 52.03 & 7.033 & 45 & 66 & \\
Post Test & 33 & 42.39 & 6.941 & 33 & 60 & .000 \\
\hline
\end{tabular}

Berdasarkan hasil dari uji Wilcoxon tabel 3 menunjukkan bahwa terdapat perbedaan sebelum dilakukan intervensi kombinasi teknik relaksasi genggam jari dan terapi musik dan setelah diberi intervensi kombinasi teknik relaksasi genggam jari dan terapi music. Hal tersebut menunjukkan bahwa terdapat pengaruh kombinasi teknik relaksasi genggam jari dan terapi music terhadap penurunan kecemasan ibu pre sectio caesarea di RSUD Ungaran dengan $p$ value 0.000. Berdasarkan tabel di atas menunjukkan rerata penurunan kecemasan pre test dengan nilai mean 52.03 dan post test sebesar 42.39 .

\section{PEMBAHASAN}

Gambaran Tingkat Kecemasan Ibu Pre Sectio Caesarea Sebelum Dilakukan Intervensi Kombinasi Teknik Relaksasi Genggam Jari dan Terapi Musik

Hasil penelitian yang disajikan pada tabel 4.2 menunjukkan bahwa responden mayoritas mengalami kecemasan ringan sebanyak 24 responden $(72,7 \%)$ dan yang mengalami kecemasan sedang sebanyak 9 responden $(27,3 \%)$. Hal ini sesuai dengan penelitian yang dilakukan Sari (2016) yang menunjukkan bahwa mayoritas responden memiliki tingkat kecemasan ringan sebanyak 10 responden $(62,5 \%)$ pada kelompok kontrol dan 9 responden $(56,3 \%)$ pada kelompok intervensi.

Perasaan cemas pada ibu yang akan melakukan persalinan sectio caesarea merupakan hal yang wajar karena ibu merasa khawatir dengan kondisi dirinya dan bayinya. Ibu yang akan melakukan operasi akan mengalami reaksi emosional berupa kecemasan. Kecemasan yang mungkin dialami oleh pasien akan mempengaruhi respon fisiologis tubuh. Timbulnya rasa cemas pada ibu pre sectio caesarea dapat dipengaruhi karena ibu memikirkan kondisi bayinya disamping ibu memikirkan kondisi dirinya sendiri (Sriningsih \& Afriani, 2014).

Pada setiap individu dapat mengalami tingkat kecemasannya yang berbeda-beda meskipun individu tersebut mengalami permasalahan yang sama. Terdapat berbagai 
tingkatan kecemasan yaitu tingkatan kecemasan ringan, sedang dan berat atau panik (Baradero, 2015). Antar individu dalam menunjukkan kecemasannya mungkin tidak sama, ada berbagai tanda kecemasan yang ditunjukkan seperti adanya peningkatan tekanan darah, tampak gelisah dan adanya perubahan pola tidur (Baradero, dkk, 2008).

Ibu yang menjalani persalinan akan dipengaruhi beberapa faktor diantaranya tingkat pengetahuan, dukungan suami maupun keluarga, faktor ekonomi dan faktor psikologis. Pengalaman berhubungan dengan sikap dan perilaku yang didasari oleh adanya pengetahuan, dimana seorang ibu mengalami kecemasan dengan tidak mengetahui atau memahami mengenai proses persalinannya. Kurangnya informasi yang diperoleh maupun kurang memahami mengenai proses persalinan dapat menimbulkan rasa cemas yang terjadi pada ibu yang akan melakukan persalinan dengan tingkat pengetahuan rendah tentang proses persalinan (Notoatmodjo, 2010).

\section{Gambaran Tingkat Kecemasan Ibu Pre Sectio Caesarea Sesudah Dilakukan Intervensi Kombinasi Teknik Relaksasi Genggam Jari dan Terapi Musik}

Hasil penelitian yang ditunjukkan pada tabel 2 menunjukkan bahwa setelah dilakukan intervensi kombinasi teknik relaksasi genggam jari dan terapi musik mayoritas tidak mengalami cemas sebanyak 21 responden $(63,6 \%)$, yang mengalami kecemasan ringan sebanyak 11 responden $(33,3 \%)$, namun masih terdapat 1 responden $(3,0 \%)$ yang mengalami kecemasan sedang.

Untuk rerata penurunan tingkat kecemasan yang ditunjukkan pada tabel 4 didapatkan hasil pre test dengan nilai mean 52.03 dan hasil post test sebesar 42.39 . Hal ini menunjukkan bahwa rerata penurunan tingkat kecemasan pre dan post test mengalami penurunan yang cukup signifikan.

Relaksasi genggam jari merupakan sebuah teknik relaksasi yang sangat sederhana dan mudah dilakukan oleh siapapun yang berhubungan dengan jari tangan serta aliran energi di dalam tubuh. Teknik relaksasi genggam jari dapat mengurangi ketegangan otot sehingga akan mengurangi kecemasan (Yuliastuti, 2015). Menggenggam jari dan menarik nafas dalam-dalam dapat mengurangi dan menyembuhkan ketegangan fisik dan emosi, karena menggenggam jari akan menghangatkan titik-titik keluar masuknya energi pada meridian (saluran energi) yang berhubungan dengan organ - organ di dalam tubuh serta emosi yang terletak pada jari tangan kita.

Pada saat genggaman jari, titik - titik refleksi pada tangan akan memberikan rangsangan secara spontan. Rangsangan tersebut akan mengalirkan semacam gelombang kejut atau listrik menuju ke otak kemudian diproses secara cepat dan kemudian diteruskan menuju syaraf pada organ tubuh yang mengalami gangguan, sehingga sumbatan di jalur energi menjadi lancar. Sumbatan di jalur energi tersebut merupakan perasaan yang tidak seimbang seperti perasaaan khawatir, kecemasan, marah, takut, dan kesedihan yang dapat menghambat aliran energi di dalam tubuh dan mengakibatkan ketidaknyamanan dalam tubuh (Hill, 2011). 
Intervensi teknik relaksasi genggam jari tersebut dikombinasikan dengan terapi music. Musik merupakan suatu komponen yang dinamis yang dapat mempengaruhi psikologis dan fisiologis bagi pendengarnya. Musik adalah paduan rangsang suara yang membentuk getaran yang dapat memberikan rangsang pada pengindraan, organ tubuh dan emosi. Ini berarti, individu yang mendengarkan musik akan memberi respon, baik secara fisik maupun psikis, yang akan menggugah sistem tubuh, termasuk aktivitas kelenjar-kelenjar di dalamnya (Nilsson, 2009). Secara fisiologis, saat seseorang mendengarkan musik, gelombang vibrasi menstimulasi sistem limbik, sehingga individu menjadi rileks. Musik juga memengaruhi pelepasan corticotrophin-releasing hormone $(\mathrm{CRH})$, sehingga sistem saraf simpatis dan parasimpatis kembali bekerja secara seimbang dan kecemasan turun (Wilianto \& Adianti, 2012). Terapi music dapat memberikan efek yang menenangkan bagi responden, dapat mengurangi kegelisahan, membuat perasaan menjadi rileks, santai, serta dapat menstabilkan emosional.

\section{Pengaruh Kombinasi Teknik Relaksasi Genggam Jari dan Terapi Musik Terhadap Penurunan Kecemasan Ibu Pre Sectio Caesarea}

Hasil penelitian menggambarkan tingkat kecemasan setelah diberikan intervensi, 8 responden turun ke tingkat kecemasan ringan yang sebelumnya mengalami kecamasan sedang, untuk 21 responden menjadi tidak mengalami kecemasan yang sebelumnya mengalami kecemasan ringan, namun ada 3 responden dengan kecemasan masih tetap pada tingkat kecemasan ringan dan 1 responden yang masih tetap mengalami kecemasan sedang. Hal tersebut menunjukkan bahwa terdapat penurunan tingkat kecemasan pada ibu pre sectio caesarea sebelum dan sesudah diberi intervensi kombinasi teknik relaksasi genggam jari dan terapi musik dengan hasil pengujian hipotesis menggunakan uji Wilcoxon menunjukkan hasil $p$ value 0.000 ( $p$ <.05) maka Ho ditolak dan Ha diterima yang artinya ada pengaruh dari kombinasi teknik relaksasi genggam jari dan terapi musik terhadap penurunan kecemasan ibu pre sectio caesarea di RSUD Ungaran.

Berdasarkan penelitian Sari (2016) menunjukkan bahwa setelah diberi intervensi teknik relaksasi genggam jari, tingkat kecemasan pada kelompok perlakuan mengalami penurunan kecemasan yang signifikan sedangkan pada kelompok kontrol tidak mengalami penurunan tingkat kecemasan yang signifikan. Didapatkan hasil pengujian hipotesis $p<0.05$ yang membuktikan bahwa adanya pengaruh pemberian teknik relaksasi genggam jari untuk menurunkan tingkat kecemasan pada pasien menjelang operasi sectio caesarea.

Berdasarkan penelitian Savitri, dkk (2016) didapatkan hasil signifikan terhadap penurunan tingkat kecemasan pada pasien pre operasi setelah diberikan terapi musik. Hasil analisis statistic dengan Independent Sample t-test diperoleh $p<0.05$, artinya ada pengaruh terapi musik terhadap tingkat kecemasan pasien pre operasi.

Penelitian Supriyanti dan Keumalahayati (2015) menunjukkan bahwa terdapat perbedaan yang signifikan antara kelompok kontrol dan kelompok intervensi sebelum dan sesudah diberi intervensi terapi music untuk menurunkan tingkat 
kecemasan pada ibu yang pre sectio caesarea dengan didapatkan hasil $p$ value $0.041(p<0.05)$ yang berarti terdapat pengaruh terapi musik untuk menurunkan tingkat kecemasan ibu pre sectio caesarea.

\section{SIMPULAN DAN SARAN \\ Simpulan}

Pada analisis uji Wilcoxon menunjukkan nilai $p$ value $0,000(\mathrm{p}<0,05)$ artinya ada perbedaan sebelum dan sesudah diberikan intervensi. Hasil penelitian menunjukkan bahwa ada pengaruh dari kombinasi teknik relaksasi genggam jari dan terapi musik terhadap penurunan kecemasan ibu pre sectio caesarea di RSUD Ungaran.

\section{Saran}

RSUD Ungaran diharapkan dapat melakukan inovasi dalam pemberian intervensi manajemen ansietas dengan teknik non farmakologis salah satunya dengan menerapkan kombinasi teknik relaksasi genggam jari dan terapi music untuk mengatasi kecemasan ibu pre sectio caesarea yang bertujuan agar pasien dapat mengatasi kecemasan secara mandiri. Peneliti selanjutnya diharapkan peneliti selanjutnya untuk menentukan homogenitas responden pada karakteristik riwayat sectio caesarea.

\section{REFERENSI}

Baradero, M., Dayrit, M. W., \& Siswadi, Y. (2008). Prinsip \& Praktik Keperawatan Perioperatif. Jakarta: EGC.

Baradero, Mary., dkk. (2015). Seri Asuhan keperawatan Kesehatan Mental Psikiatri. Jakarta : EGC

Breathesy. (n.d.). Blood Pressure Reduction : Frequently asked question on nervous pre operation. Journal of Blood Vol. 8, No. 2, 112-118.

Hill, R. Y. (2011). Nursing from the inside-out:Living and nursing from the highest point of your consciousness. London: Jones and Barlett Publishers

Nilsson, U. (2009). Caring Music : Music Intervention For Improved Health. (http://www.orebroll.se/uso/page_2436.aspx). Diakses 24 November 2018.

Notoatmojo. (2010). Metodologi Penelitian Kesehatan. Jakarta: Rineka Cipta.

Pawatte, I., Pali, C., Opod, H. (2013). Perbedaan Tingkat Kecemasan Pada Ibu Pre Seksio Caesarea di RSIA Kasih Ibu dan RSUP. Prof. Dr. D. Kandou Manado. Jurnal Kedokteran Komunitas dan Tropik, vol. 1, no. 3

Reeder, S. J., Martin, L. L., \& Koniak-Griffin, D. (2011). Keperawatan Maternitas (Kesehatan Wanita, Bayi \& Keluarga) Edisi 18 Volume 2. Jakarta: EGC.

Rokawie, A. O., Sulastri, \& Anita. (2017). Relaksasi Nafas Dalam Menurunkan Kecemasan Pasien Pre Operasi Bedah Abdomen. Jurnal Kesehatan Vol. 8, No. 2, 257-262.

Sari, R. D. (2016). Pengaruh Teknik Relaksasi Genggam Jari Terhadap Penurunan Kecemasan Pada Pasien Pre Operasi Sectio Caesarea. Publikasi Ilmiah, 113. 
Savitri, W., Fidayanti, N., \& Subiyanto, P. (2016). Terapi Musik Dan Tingkat Kecemasan Pasien Preoperasi. Media Ilmu Kesehatan Vol. 5, No. 1, 1-6.

Simbolon, P., \& Hondro, M. R. (2015). Pengaruh Terapi Musik Terhadap Tingkat Kecemasan Pada Pasien Pre Operasi di Ruang Rawat Bedah Rumah Sakit Santa Elizabeth Medan Tahun 2015. Jurnal Keperawatan.

Supriyanti, \& Keumalahayati. (2017). Pengaruh Terapi Musik Klasik Beethoven Untuk Mnegurangi Kecemasan Ibu Bersalin Pre Operasi Sectio Caesarea di RSUD Langsa Tahun 2015. Jurnal Kesehatan Ilmiah Nasuwakes Vol. 10, No. 1, 20-28.

Wilianto, V. M., \& Adianti, M. (2012). Terapi Musik Kognitif Perilaku Untuk Menurunkan Kecemasan Pada Penderita Tekanan Darah Tinggi. Jurnal Intervensi Psikologi Vol. 4 No. 1, 87-111.

Yanti, D. A., Anggraeni, S., Sulistianingsih, A., \& Maryanti, L. (2016). Hubungan Pendidikan Dengan Kecemasan Pasien Pre Operasi Seksio Sesaria (SC) di Ruang Kebidanan Rumah Sakit Urip Sumoharjo Bandar Lampung Tahun 2015. Jurnal Asuhan Ibu \& Anak, 35-41.

Yuliastuti, C. (2015). Effect Of Handheld Finger Relaxation On Reduction Of Pain Intensity In Patients With Post-Appendectomy At Inpatient Ward, RSUD Sidoarjo. International Journal of Medicine and Pharmaceutical Sciences (IJMPS), vol 5, no 3 ; 53-58 